\title{
Structure-Function Relationship of New Anthralin Derivatives Assayed for Growth Inhibition and Cytotoxicity in Human Keratinocyte Cultures $^{+)}$
} \author{
and Wolfgang Wiegrebe ${ }^{\mathrm{b})}$. \\ a) Department of Dermatology, University of Cologne, Joseph-Stelzmann-Str. 9, D-5000 Köln 41. \\ b) Institute of Pharmacy, University of Regensburg, D-8400 Regensburg. \\ c) Institute of Clinical Chemistry, University of Cologne.
}

Bernd Bonnekoh $^{\text {a)* }}$, Helene Tanzer ${ }^{\text {b) }}$, Matthias Seidel ${ }^{\text {b) }}$, Jürgen Geisel ${ }^{\text {c) }}$, Hans F. Merk ${ }^{\text {a) }}$, Gustav Mahrle ${ }^{\text {a) }}$,

Received September 28, 1990

\begin{abstract}
$\mathrm{HaCaT}$ keratinocyte cultures were exposed to twelve hydrophilic anthralin derivatives 1 to 12 with substituents at $\mathrm{C}-1$ and $\mathrm{C}-8$ of the anthrone skeleton, of one $\mathrm{H}$ at C-10 and of both H's at C-10 by lacton rings (fig. 1). After $3 \mu \mathrm{M}$ treatment growth was determined by cellular protein content, ${ }^{3} \mathrm{H}$-thymidineand ${ }^{14} \mathrm{C}$-amino-acid-uptake and cytotoxicity by the release of cytoplasmic LDH into the culture medium.- In comparison to acetone control (100\%) anthralin suppressed mean protein content, as well as DNA- and protein-synthesis to 33,28 , and $21 \%$, respectively, and the drug revealed an enzyme release of $660 \%$. In relation to the parent drug we found similar cell growth inhibitory effects of compounds $4,6,8,9,10$, and 12. Deriv. 4, 8, and 10 were, however, to some extent less cytotoxic than anthralin, whereas deriv. 6, 9, and 12 were in the same range. An extreme suppression of growth parameters which differed from the anthralin effect by a factor 0.5-0.8 was caused by deriv. 11, showing the same cytotoxicity. Deriv. 1, 2, 3, 5, and 7 did not demonstrate any cytotoxicity. Concerning growth parameters, deriv. 2 induced a slight stimulation, deriv. 3 and 7 were completely ineffective, deriv. 1 and 5 induced slightly to moderately inhibited proliferation but both being much less effective than anthralin. These data indicate that the "minimum structure" concept by Krebs and Schaltegger - claiming 1-hydroxy-9anthrone as a precondition for clinical antipsoriatic potency - is not valid at least in cell-biological tests and point toward possible usefulness of some experimental model compounds as alternative antipsoriatics.
\end{abstract}

Beurteilung von Struktur-Wirkungs-Beziehungen neuer Anthralin-Derivate aufgrund der Zellwachstumshemmung und Zytotoxizität in Humankeratinozyten-Kulturen

In HaCaT Keratinozyten-Kulturen wurden zwölf hydrophile Dithranol-Derivate 1 bis 12 untersucht, die Substituenten an C-1 und C-8 des Anthrongerüsts, an $\mathrm{C}-2$, an Stelle eines $\mathrm{H}$-Atoms an $\mathrm{C}-10$ und an Stelle beider $\mathrm{H}$ an C-10 Lacton-Ringe aufweisen (Fig. 1). Nach der Behandlung mit $3 \mu \mathrm{M}$ Substanz wurde das Zellwachstum bestimmt anhand des zellulären Proteingehalts, ${ }^{3} \mathrm{H}$-Thymidin- und ${ }^{14} \mathrm{C}$-Aminosäuren-Einbaus; die Zytotoxizität war durch die extrazelluläre Freisetzung der zytoplasmatischen Lactatdehydrogenase erfaßbar.- Im Vergleich zu der Aceton-Kontrolle (100\%) erniedrigte Dithranol den Proteingehalt, die DNA- und Protein-Synthese im Mittel auf 33, 28 bzw. $21 \%$, dabei kam es zu einer Enzymfreisetzung von $660 \%$. Im Vergleich zu Dithranol fanden wir ähnliche Hemmungen des Zellwachstums für die Derivate 4, 6, 8, 9, 10 und 12. Die Derivate 4, 8 und 10 waren jedoch weniger zytotoxisch als Dithranol, wohingegen die Derivate 6, 9 und 12 diesbezüglich im gleichen Bereich lagen. Eine extreme Hemmung der Wachstumsparameter, wobei diese vom Dithranol-Effekt um einen Faktor 0.5 bis 0.8 abwichen, ergab sich für das Derivat 11, welches gleich stark zytotoxisch wirkte. Die Derivate 1, 2, 3, 5 und 7 waren nicht zytotoxisch. Bezüglich der Wachstumsparameter ließ sich feststellen, daß das Derivat 2 leicht stimulierte, die Derivate 3 und 7 vollständig unwirksam waren und die Derivate 1 und 5 das Zellwachstum leicht bis mäßig hemmten, aber die Hemmung viel geringer ausgeprägt war als die durch Dithranol. Die Ergebnisse zeigen, daß a) das von Krebs und Schaltegger begründete Konzept der "Minimalstruktur" - demzufolge die 1-Hydroxy-9-anthron-Struktur eine Voraussetzung für klinische antipsoriatische Wirksamkeit eines Anthrons darstellt - zumindest für zellbiologische Tests nicht allgemein gültig ist und weisen b) auf eine mögliche weitergehende Bedeutung einzelner dieser Modell-Substanzen als antipsoriatische Alternativ-Therapeutika hin.
Although anthralin (syn. dithranol) is a classic topical antipsoriatic, there is still a controversial debate concerning its exact biochemical mode of action. The drug is known to suppress various parameters of cell metabolism, e.g. DNA-replication and -repair ${ }^{1,2,3,4)}$, protein-synthesis ${ }^{3)}$, mitochondrial respiration ${ }^{5,6,7,8)}$, activities of cytosolic glucose-6-phosphate-dehydrogenase $^{9,10,11)}$, calmodulin ${ }^{12)}$, thioredoxin-reductase ${ }^{13,14)}$, plasminogenactivator $^{15)}$, arachidonic acid lipoxygenase ${ }^{16)}$, and superoxide anion generation in neutrophils ${ }^{17)}$. Comparative dose response studies have favored mitochondrial respiration as the primary cellular target ${ }^{18,19,20)}$. With regard to the sequel of subcellular drug effects, to a great extent the experimental difficulties derive from anthralin's instability through oxidation generating a cascade of radicals assumed to be the immediate effectors of cytotoxicity $^{21,22,23)}$.

Much of the experimental work is impeded by the low degree of solubility of anthralin in aqueous systems ${ }^{9,24)}$. This could be overcome by developing and using hydrophilic anthralin derivatives as drug models. Therefore, the present study deals with twelve more aqueous soluble anthralin derivatives (deriv. 1 to 12) with hydrophilic groups

\footnotetext{
${ }^{+)}$Dedicated to Prof. Dr. Dr. h.c. Gerd Klaus Steigleder on the occasion of his 65th birthday.
} 
<smiles>O=C1c2c(O)cccc2Cc2cccc(O)c21</smiles>

Anthralin<smiles>O=C1C(=O)c2c(O)cccc2C(c2ccccc2O)c2cccc(O)c21</smiles><smiles>O=C1c2cccc(O)c2C(=O)c2cccc(O)c21</smiles>

Danthrone

\section{Bianthrone}<smiles>COc1cccc2c1C(=O)c1c(cccc1OC)C2</smiles><smiles>O=C(O)CCc1ccc2c(c1O)C(=O)c1c(O)cccc1C2</smiles><smiles>CC(=O)CCc1ccc2c(c1O)C(=O)c1c(O)cccc1C2</smiles><smiles>CC(=O)CC1c2cccc(O)c2C(=O)c2c(O)cccc21</smiles><smiles>CC(=O)CC(=O)OC(C)=O</smiles><smiles>CC(=O)Oc1c(C(C)=O)c2ccccc2c(=O)c2c(O)cccc12</smiles>

No.

$n=2$

$n=1$

$n=2$

$n=3$

$n=4$

$n=2$

$n=3$

$n=2$

$n=3$

$n=4$
Figure 1: Structural formulas of anthralin, bianthrone, danthrone, and the anthralin derivatives 1 to 12 used in this study.

synthesized recently ${ }^{24,25)}$. This panel of derivatives (fig. 1) contains a 1,8-dimethoxy-compound [1] as well as C-2 [2 to 5] and C-10 [6 to 12] substituted anthrones. The reason for in vitro screening is the ongoing search for a derivative having antipsoriatic efficacy but lacking skin irritancy or staining of skin (clothes), which both still represent the main disadvantages of clinical anthralin application.

With regard to psoriatic epidermal hyperproliferation we used $\mathrm{HaCaT}$ cells, a rapidly multiplying human keratinocyte line $^{26)}$, as an assay system. This has been described as being extremely sensitive to anthralin as evidenced by a $50 \%$ inhibition concentration $\left(\mathrm{IC}_{50}\right)$ of $0.2 \mu \mathrm{M}$ for DNA synthesis and by a significant release of lactate dehydrogenase (indicating cytotoxicity) at a relatively low concentration of 0.3 $\mu \mathrm{M}^{27}$.

\section{Abbreviations}

DMEM: Dulbecco's modified Eagle's medium G-6-PDH: glucose-6phosphate dehydrogenase $\mathrm{IC}_{50}: 50 \%$ inhibition concentration $\mathrm{LDH}$ : lactate dehydrogenase

\section{Test Compounds}

Figure 1 shows the structural formulas of anthralin, its oxidation products bianthrone and danthrone, and twelve anthralin derivatives applied in this study. All test compounds were dissolved in acetone at $3.0 \mathrm{mM}$ under light protection. The solutions were then diluted 1:1000 with Dulbecco's modified Eagle's medium (DMEM, Flow Cat. No. 12-332-54) which was used serum-free in order to avoid binding or inactivation of the test compounds by serum constituents ${ }^{3}$. All solutions were prepared immediately before use.

\section{HPLC-Monitoring of Anthralin Stability}

With regard to our special cell culture conditions we prechecked the stability of anthralin which was dissolved at $3 \mu \mathrm{M}$ in $0.1 \%$ acetone and serum-free DMEM at $37^{\circ} \mathrm{C}$ under $10 \% \mathrm{CO}_{2}$. After adding the drug to the cell-free medium, several samples were taken and analysed by HPLC during the following $240 \mathrm{~min}^{25}$.

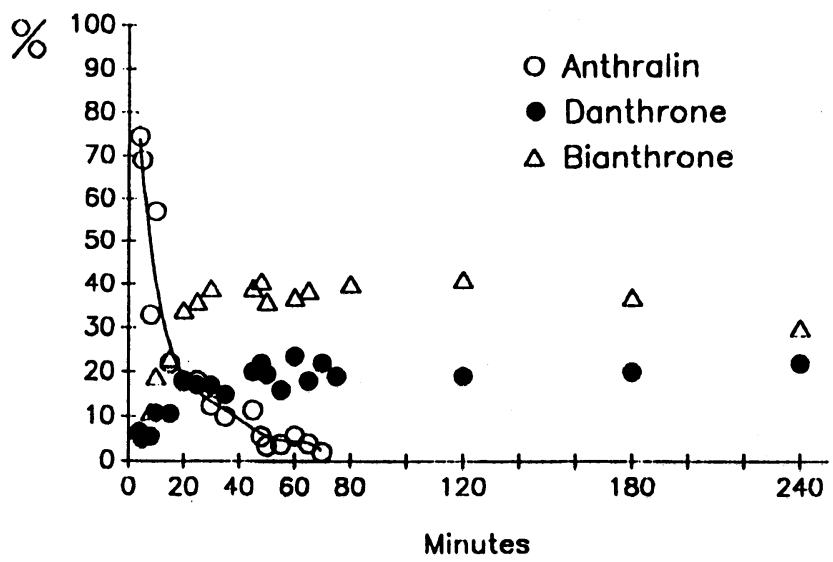

Figure 2: Decay kinetics of anthralin which was dissolved at $3 \mu \mathrm{M}$ in serum-free Dulbecco's modified Eagle's medium (DMEM) containing $0.1 \%$ acetone $\left(37^{\circ} \mathrm{C}, 10 \% \mathrm{CO}_{2}\right)$. The drug and its main oxidation products bianthrone and danthrone were detected by $\mathrm{HPLC}^{\mathrm{A2})}$ and recorded as relative amounts of total substance.

\section{Cell-Culture}

HaCaT cells ${ }^{*}$ were seeded in Greiner 24-well-multidishes and grown in DMEM, supplemented with $1 \%$ antibiotic-antimycotic-solution (Gibco Cat. No. 043-5240H), 4 mM L-glutamine (Gibco Cat. No. 043-5030H) and $10 \%$ fetal calf serum (Gibco Cat. No. $011-6290 \mathrm{H}$ ) at $37^{\circ} \mathrm{C}$ in a humidified atmosphere of $10 \% \mathrm{CO}_{2}$. Exposure to test compounds was performed on subconfluent cultures at log-growth-phase, which was reached one day after plating of $4 \times 10^{4}$ cells per $1.8 \mathrm{~cm}^{2}$ (series 1) or three days after plating of $1 \times 10^{4}$ cells (series 2). The cultures were rinsed two times with DMEM and incubated with $3.0 \mu \mathrm{M}$ test compound in DMEM $(0.1 \%$ acetone, as described above) for $\mathbf{3 0} \mathrm{min}$; control cultures were exposed to DMEM containing $0.1 \%$ acetone. Subsequently, the supernatants were dis-

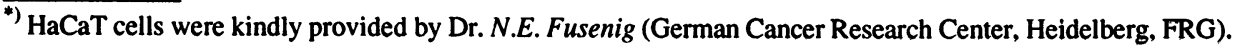


carded and cultivation was continued in the complete growth medium including serum until the 2 nd day after the test compound exposure.

For measurement of cytotoxicity by LDH release we employed a protocol which has been described in detail ${ }^{27)}$.- In brief, $1.8 \times 10^{6} \mathrm{HaCaT}$ cells were seeded in a culture flask $\left(75 \mathrm{~cm}^{2}\right.$, Falcon) and grown to post-confluency for $\mathbf{1 4}$ days. The cells were incubated with the test compounds for $30 \mathrm{~min}$ (see above) and thereafter kept in $13 \mathrm{ml}$ of fresh DMEM during the following $24 \mathrm{~h}$ (see below).

\section{Measurement of Cellular Protein}

$48 \mathrm{~h}$ after exposure with the test compounds, the protein content of attached cells was determined by a modified Bradford method ${ }^{3,28)}$. In brief, the cultures were rinsed twice with methanol and dried in the air. The cells were overlayered with $1.5 \mathrm{ml}$ of $0.5 \mathrm{~N} \mathrm{NaOH}$ per well and kept under occlusion by means of a Parafilm foil in order to prevent evaporation. After the wells had been gently agitated at room temp. for $16 \mathrm{~h}$, the probes were stained with BioRad-reagent (Cat. No. 500-0006) and photometrically measured at $595 \mathrm{~nm}$ against bovine serum albumin standard.

\section{Incorporation of ${ }^{3} \mathrm{H}$-thymidine and ${ }^{14} \mathrm{C}$-amino-acids}

$48 \mathrm{~h}$ after treatment with the test compounds cultures were pulse labeled $(2 \mathrm{~h})$ simultaneously with $1.0 \mu \mathrm{Ci}$ methyl- ${ }^{3} \mathrm{H}$-thymidine (specific activity 77.9 Ci/mmol, NEN DuPont, 6380 Bad Homburg, FRG, NET-027Z) and $0.5 \mu \mathrm{Ci}{ }^{14} \mathrm{C}$-amino-acids (mixture of 15 different amino acids, specific activity $1.85 \mathrm{GBq} /$ milligramatom of carbon, Amersham, 3300 Braunschweig, FRG, CFB.104) in $1 \mathrm{ml}$ DMEM per well of the multidish. Cells were then trypsinized with $0.05 \%$ trypsin/0.02\% EDTA (Gibco Cat. No. $043-5300 \mathrm{M}$ ) for $45 \mathrm{~min}$ at $37^{\circ} \mathrm{C}$ and precipitated with $5 \%$ trichloroacetic acid. The cell material was harvested by an Inotech apparatus and counted in a Rackbeta scintillation counter (LKB) using the two channel mode. The incorporation of ${ }^{3} \mathrm{H}$-thymidine and ${ }^{14} \mathrm{C}$-amino-acids per well was taken as a measure for DNA and protein synthesis of the cultures ${ }^{3,29}$.

\section{Lactate Dehydrogenase (LDH) Release Assay}

The supernatants of cultures which had been treated with the test compounds $24 \mathrm{~h}$ previously were collected for the determination of the extracellular LDH activity. According to the recommendations of the German Society for Clinical Chemistry an optimized standard method of the photometric measurement was performed using a Boehringer Mannheim test kit for BM/Hitachi system $737^{27,30,31)}$.

\section{Morphological Monitoring}

$48 \mathrm{~h}$ after incubation, cultures were examined by phase contrast microscopy. The morphological evaluation was performed with special regard to: a) density of attached cells, b) loss of regular "cobble-stone-pattern" with widened intercellular spaces, c) extent of cell detachment, d) alteration of cell shape, e.g. impeded cell-spreading, ballooning, pycnotic shrinking, fragmentation, and e) cytoplasmic changes, e.g. vacuolization or condensation $^{32,33)}$.

\section{Study Design and Statistical Analysis}

The test compounds were studied for their influence on the four mentioned parameters (protein content, thymidineand amino-acid-incorporation, LDH release) in two series of investigations. Series 1 consisted of a simultaneous testing of bianthrone, danthrone, deriv. 1, 3, 5, 7, 8, 10, and 12; deriv. 2, 4, 6, 9, and 11 were tested in series 2 . Both series included a control with $0.1 \%$ acetone as well as a standard with anthralin. Growth studies were conducted in at least six culture wells in three independent experiments (total: 18 cultures) for each compound, and the enzyme release studies were performed in three culture flasks, each in triplicate (total: 9 cultures). For each experiment and parameter the mean value of the acetone control was taken as $100 \%$. Statistical comparisons on the relative data pooled from the three experiments were performed according to Mann and Whitney (U-test $\left.{ }^{34}\right)$. Multiple comparisons required Bonferroni's adjustment ${ }^{35)}$, with an overall level of significance $\alpha$ $<0.05$ corresponding to $\mathrm{p}<0.005$ (series 1 ) and $\mathrm{p}<0.0083$ (series 2).

\section{Results}

HPLC monitoring revealed that under cell-free conditions anthralin dissolved with acetone $0.1 \%$ in DMEM $\left(37^{\circ} \mathrm{C}\right.$, $10 \% \mathrm{CO}_{2}$ ) decomposed at a rate of $31 \%$ at $5 \mathrm{~min}, 78 \%$ at 15 $\mathrm{min}, 87 \%$ at $30 \mathrm{~min}$, and $98 \%$ at $70 \mathrm{~min}$. The main oxidation products found were bianthrone and danthrone reaching a plateau of $41 \%$ and $24 \%$ at 48 and $60 \mathrm{~min}$, respectively. These data (fig. 2) prompted us to restrict the exposure time for all compounds to $30 \mathrm{~min}$.

The data of the protein content, ${ }^{3} \mathrm{H}$-thymidine- and ${ }^{14} \mathrm{C}$ amino-acid-incorporation of attached cells are compiled in table 1, 2, and 3. Setting the values for acetone at $100 \%$ (control) we found a similar inhibition of cell growth by anthralin in both series 1 and 2, that means a reduced mean cellular protein content of 31 and 35\%, DNA-synthesis of 19 and $36 \%$ as well as protein-synthesis of 16 and $25 \%$, respectively. Statistical comparison of these data for acetone and anthralin with the growth values of the different test compounds are shown in tables 1,2 , and 3 .

In both series the mean LDH release by anthralin exceeded that of the acetone controls by a factor $>6$. These results, which represent a measure for cytotoxicity, are calculated on a percentage level in table 4 , which also shows statistical comparison of the different compounds with the acetone control and anthralin.

In the phase contrast microscope we found morphological alterations which were strictly correlated with the above mentioned effects on cell growth and toxicity-dependent LDH release of the tested compounds. Thus the state of cell growth and the cytotoxicity were reflected by the density of adherent keratinocytes and the cell degeneration phenomena described in detail under "Material and Methods". Representative examples of the morphological findings after treatment with the rather effective deriv. 10 and the uneffective deriv. 3 are given in fig. 3 .

\section{Discussion}

\section{"Minimum structure" concept}

Krebs and Schaltegger ${ }^{36,37)}$ tested about 30 different anthrones for their efficacy in psoriatic patients. They found a potent effect only for anthralin, chrysarobin (1,8-dihydroxy3-methyl-9-anthrone), 1-hydroxy-9-anthrone, and 1,8,9- 

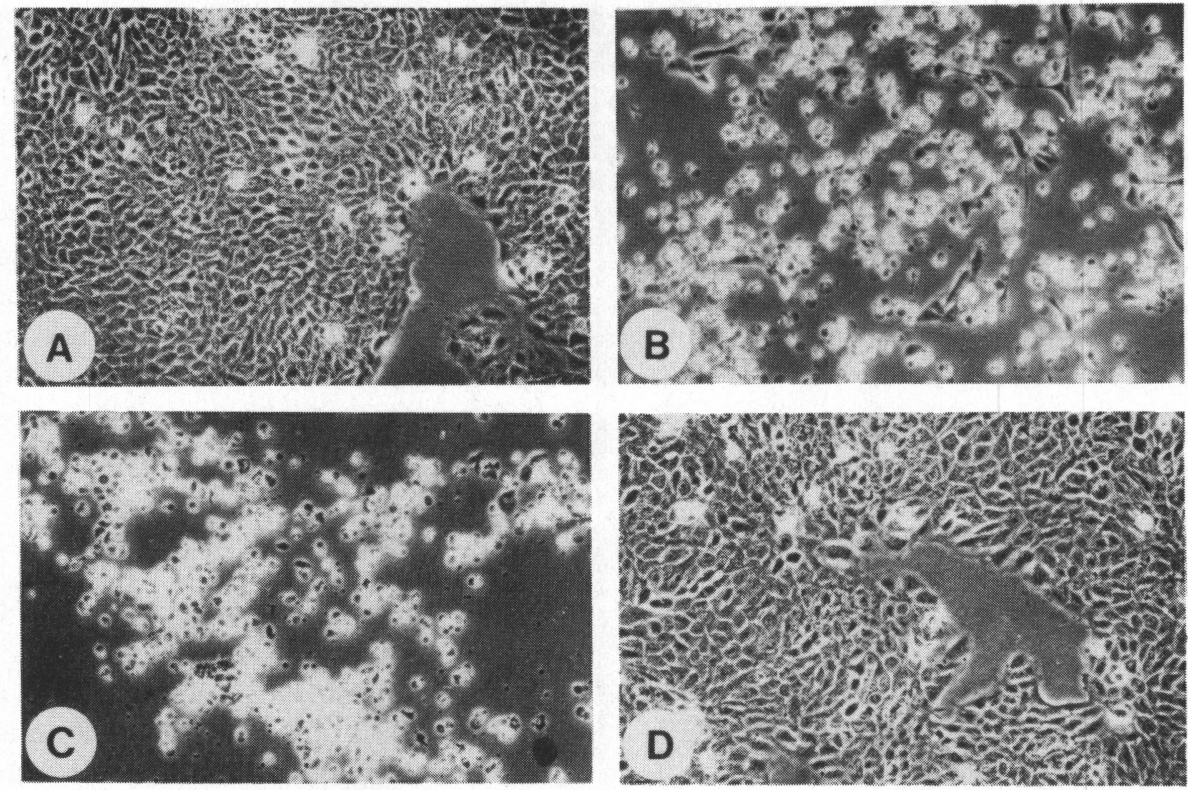

Figure 3: Phase contrast microscopy of cultured HaCaT keratinocytes two days after 30 min treatment with $0.1 \%$ acetone (A), with $3.0 \mu \mathrm{M}$ anthralin (B), and with $3.0 \mu \mathrm{M}$ of 10 (C) and 3 (D). In comparison to the acetone control, anthralin and deriv. 10 revealed signs of marked inhibition of cell growth and cytotoxicity, i.e. reduced density of attached cells, increased number of detached and deformed cells. With deriv. 3 there was no obvious difference compared to the control $(60 \mathrm{x})$.

Table 1: Protein content of attached HaCaT keratinocytes per culture two days after exposure to anthralin derivatives 1 to 12 . Significant differences at an overall level $\alpha<0.05$ are indicated by asterisks.

\begin{tabular}{|c|c|c|c|c|}
\hline \multirow{3}{*}{$\frac{\text { Incubation }}{\text { Test Compound }}$} & \multirow[t]{3}{*}{ Series } & \multicolumn{2}{|c|}{ Protein content } & \\
\hline & & \multirow[t]{2}{*}{$\begin{array}{l}\text { Percentage } \\
\text { ( mean } \pm \text { s.d. ) }\end{array}$} & \multicolumn{2}{|c|}{$\begin{array}{c}\text { Statistical Comparison ( } \mathrm{p} \text { ) } \\
\text { of the Test compound } \\
\text { versus }\end{array}$} \\
\hline & & & Acetone & Anthralin \\
\hline Acetone & 1 & $100.0 \pm 2.5$ & - & $0.0000 *$ \\
\hline Anthralin & 1 & $31.0 \pm 15.4$ & $0.0000^{*}$ & - \\
\hline Bianthrone & 1 & $31.8 \pm 12.8$ & $0.0000^{*}$ & 0.4619 \\
\hline Danthrone & 1 & $89.4 \pm 12.0$ & $0.0014^{*}$ & $0.0000 *$ \\
\hline Deriv. 1 & 1 & $90.8 \pm 8.8$ & $0.0021^{*}$ & $0.0000^{*}$ \\
\hline Deriv. 3 & 1 & $103.0 \pm 5.1$ & 0.0736 & $0.0000^{*}$ \\
\hline Deriv. 5 & 1 & $67.0 \pm 9.9$ & $0.0000^{*}$ & $0.0000 *$ \\
\hline Deriv. 7 & 1 & $106.3 \pm 10.0$ & 0.0290 & $0.0000^{*}$ \\
\hline Deriv. 8 & 1 & $28.1 \pm 8.5$ & $0.0000^{*}$ & 0.9129 \\
\hline Deriv. 10 & 1 & $27.3 \pm 7.3$ & $0.0000^{*}$ & 0.9626 \\
\hline Deriv. 12 & 1 & $24.5 \pm 7.4$ & $0.0000^{*}$ & 0.3888 \\
\hline Acetone & 2 & $100.0 \pm 10.8$ & - & $0.0000^{*}$ \\
\hline Anthralin & 2 & $34.9 \pm 7.9$ & $0.0000^{*}$ & - \\
\hline Deriv. 2 & 2 & $107.6 \pm 16.2$ & $0.0024^{*}$ & $0.0000 *$ \\
\hline Deriv. 4 & 2 & $35.5 \pm 14.0$ & $0.0000^{*}$ & 0.5657 \\
\hline Deriv. 6 & 2 & $47.9 \pm 24.6$ & $0.0000^{*}$ & 0.0120 \\
\hline Deriv. 9 & 2 & $32.0 \pm 12.2$ & $0.0000 *$ & 0.1447 \\
\hline Deriv. 11 & 2 & $26.8 \pm 10.5$ & $0.0000^{*}$ & $0.0014^{*}$ \\
\hline
\end{tabular}


Table 2: DNA-synthesis per culture two days after exposure of HaCaT keratinocytes to various test compounds. Significant differences at an overall level $\alpha<0.05$ are indicated by asterisks.

\begin{tabular}{|c|c|c|c|c|}
\hline \multirow{3}{*}{$\begin{array}{l}\text { Incubation } \\
\text { Test Compound }\end{array}$} & \multirow[t]{3}{*}{ Series } & \multicolumn{3}{|c|}{ 3H-Thymidine Incorporation } \\
\hline & & \multirow[t]{2}{*}{$\begin{array}{l}\text { Percentage } \\
(\text { mean } \pm \text { s.d. })\end{array}$} & \multicolumn{2}{|c|}{$\begin{array}{c}\text { Statistical Comparison ( } p \text { ) } \\
\text { of the Test compound } \\
\text { versus }\end{array}$} \\
\hline & & & Acetone & Anthralin \\
\hline Acetone & 1 & $100.0 \pm 19.1$ & - & $0.0000^{*}$ \\
\hline Anthralin & 1 & $19.2 \pm 12.3$ & $0.0000^{*}$ & - \\
\hline Bianthrone & 1 & $33.2 \pm 24.0$ & $0.0000^{*}$ & 0.0186 \\
\hline Danthrone & 1 & $94.1 \pm 25.6$ & 0.3888 & $0.0000^{*}$ \\
\hline Deriv. 1 & 1 & $93.9 \pm 20.7$ & 0.3550 & $0.0000^{*}$ \\
\hline Deriv. 3 & 1 & $101.9 \pm 12.8$ & 0.2788 & $0.0000^{*}$ \\
\hline Deriv. 5 & 1 & $75.6 \pm 17.0$ & $0.0001 *$ & $0.0000^{*}$ \\
\hline Deriv. 7 & 1 & $108.7 \pm 10.4$ & 0.0847 & $0.0000^{*}$ \\
\hline Deriv. 8 & 1 & $12.3 \pm 3.4$ & $0.0000^{*}$ & 0.0320 \\
\hline Deriv. 10 & 1 & $11.4 \pm 4.3$ & $0.0000^{*}$ & 0.0083 \\
\hline Deriv. 12 & 1 & $7.8 \pm 4.8$ & $0.0000^{*}$ & $0.0000^{*}$ \\
\hline Acetone & 2 & $100.0 \pm 26.4$ & - & $0.0000^{*}$ \\
\hline Anthralin & 2 & $36.1 \pm 8.5$ & $0.0000^{*}$ & - \\
\hline Deriv. 2 & 2 & $148.4 \pm 44.1$ & $0.0000^{*}$ & $0.0000^{*}$ \\
\hline Deriv. 4 & 2 & $38.1 \pm 7.0$ & $0.0000^{*}$ & 0.1710 \\
\hline Deriv. 6 & 2 & $48.5 \pm 15.8$ & $0.0000^{*}$ & $0.0010^{*}$ \\
\hline Deriv. 9 & 2 & $21.1 \pm 5.9$ & $0.0000^{*}$ & $0.0000^{*}$ \\
\hline Deriv. 11 & 2 & $22.5 \pm 11.5$ & $0.0000^{*}$ & $0.0000^{*}$ \\
\hline
\end{tabular}

triacetoxy-anthracene; the last had been introduced by $\mathrm{Hel}$ lier and Whitefield ${ }^{38)}$. Krebs and coworker claimed 1-hydroxy-9-anthrone as the "minimum structure" of an anthrone required for clearing up psoriasis. In detail this "minimum structure" should consist of a) a hydroxy group at C-1, b) a carbonyl group at C-9, and c) a C-10 methylene group (two hydrogens). Determining the activity of isolated glucose-6-phosphate dehydrogenase (G-6-PDH), which as a key enzyme for hexosemonophosphate shunt is known to be significantly elevated in psoriatic tissue ${ }^{10)}$, Tanzer et al. ${ }^{25}$ ) demonstrated that the "minimun structure" compound had an $\mathrm{IC}_{50}$-value of $9.4 \mu \mathrm{M}$ which was very similar to $8 \mu \mathrm{M}$ for anthralin.

\section{Significance of free hydroxy group at C-1}

In accordance with the "minimum structure" concept we found that deriv. 1 characterized by methoxy groups at C-1 and C-8 was not cytotoxic and inhibited the cell growth parameters to only a very low degree. These data are in good agreement with the findings for a very similar compound, namely 1,8,9-trimethoxy-anthracene, which proved to be ineffective against psoriatic lesions ${ }^{39}$. However, contrary to the "minimum structure" concept, an animal study by Plumier et al ${ }^{40)}$ on 1,8,9-triacetoxy-anthracene revealed that the antiproliferative activity of this derivative, even though less than that of anthralin, did not depend on degradation to a "minimum structure" compound. Thus, the study denied the pro-drug character of 1,8,9-triacetoxy-anthracene which had initially been suggested ${ }^{36,37,41)}$. Also not in favor of the "minimum structure" concept was the finding that the topically applied antiproliferatively active 1,8-diacetoxy-anthracene was not converted to a compound with a free C-1 hydroxy group ${ }^{40)}$. In contrast to the results with the HaCaT keratinocytes we recently found nonphenolic anthrones to be more active as inhibitors of arachidonic acid lipoxygenase from bovine polymorphonuclear leucocytes than anthralin, suggesting a different mode of action ${ }^{42)}$.

\section{Influence of $C-2$ substitution}

Deriv. 2 and 3, which were anthrones substituted at C-2 with acetic and propionic acid increments, respectively, did not reveal any cytotoxicity or inhibition of cell growth at the $3 \mu \mathrm{M}$ concentration tested. With deriv. 2 we even found a slightly increased cell growth. These data correspond well to G-6-PDH studies demonstrating rather high IC $_{50}$ values for deriv. no. $2(38 \mu \mathrm{M})$ and $3(18 \mu \mathrm{M})$ with regard to anthralin $\left(8 \mu \mathrm{M}^{25}\right)$.

4 and 5 are methyl esters of 2 and 3. With deriv. 4 we found an identical decrease of cell growth and a reduced cytotoxicity in comparison to anthralin. For deriv. 5 cyto- 
Table 3: Protein-synthesis per culture two days after exposure of HaCaT keratinocytes to various test compounds. Significant differences at an overall level $\alpha<0.05$ are indicated by asterisks.

\begin{tabular}{|c|c|c|c|c|}
\hline \multirow{3}{*}{$\frac{\text { Incubation }}{\text { Test Compound }}$} & \multirow[t]{3}{*}{ Series } & \multicolumn{3}{|c|}{${ }^{14} \mathrm{C}$-Amino Acid Incorporation } \\
\hline & & \multirow[t]{2}{*}{$\begin{array}{l}\text { Percentage } \\
\text { ( mean } \pm \text { s. d. ) }\end{array}$} & \multicolumn{2}{|c|}{$\begin{array}{c}\text { Statistical Comparison (p) } \\
\text { of the Test compound } \\
\text { versus }\end{array}$} \\
\hline & & & Acetone & Anthralin \\
\hline Acetone & 1 & $100.0 \pm 17.3$ & - & $0.0000^{*}$ \\
\hline Anthralin & 1 & $16.2 \pm 15.5$ & $0.0000^{*}$ & - \\
\hline Bianthrone & 1 & $25.0 \pm 21.6$ & $0.0000^{*}$ & 0.0449 \\
\hline Danthrone & 1 & $91.3 \pm 28.6$ & 0.1916 & $0.0000^{*}$ \\
\hline Deriv. 1 & 1 & $94.1 \pm 19.4$ & 0.3079 & $0.0000^{*}$ \\
\hline Deriv. 3 & 1 & $104.1 \pm 11.7$ & 0.1708 & $0.0000^{*}$ \\
\hline Deriv. 5 & 1 & $72.4 \pm 14.6$ & $0.0000^{*}$ & $0.0000^{*}$ \\
\hline Deriv. 7 & 1 & $109.4 \pm 11.5$ & 0.0847 & $0.0000^{*}$ \\
\hline Deriv. 8 & 1 & $8.0 \pm 2.0$ & $0.0000^{*}$ & 0.0060 \\
\hline Deriv. 10 & 1 & $6.8 \pm 1.6$ & $0.0000^{*}$ & $0.0003^{*}$ \\
\hline Deriv. 12 & 1 & $3.4 \pm 1.3$ & $0.0000^{*}$ & $0.0000^{*}$ \\
\hline Acetone & 2 & $100.0 \pm 24.4$ & - & $0.0000^{*}$ \\
\hline Anthralin & 2 & $25.4 \pm 8.3$ & $0.0000^{*}$ & - \\
\hline Deriv. 2 & 2 & $119.1 \pm 22.0$ & $0.0004^{*}$ & $0.0000^{*}$ \\
\hline Deriv. 4 & 2 & $27.1 \pm 6.6$ & $0.0000^{*}$ & 0.4345 \\
\hline Deriv. 6 & 2 & $35.8 \pm 17.3$ & $0.0000^{*}$ & $0.0036^{*}$ \\
\hline Deriv. 9 & 2 & $12.2 \pm 3.2$ & $0.0000^{*}$ & $0.0000^{*}$ \\
\hline Deriv. 11 & 2 & $13.0 \pm 6.1$ & $0.0000^{*}$ & $0.0000 *$ \\
\hline
\end{tabular}

toxicity was lacking and slowing down of cell growth was much less pronounced than with anthralin.

\section{Significance of ligands replacing one hydrogen atom at C-10}

The "minimum structure" concept - claiming free hydrogens at C-10 for clinical antipsoriatic activity - was developed from the observation that capaloin, an anthralin derivative glucosylated at $\mathrm{C}-10$, did not clear up psoriasis $^{36,37)}$. Our data demonstrate that this postulation does not have general validity. Thus, the acid 6 effected an equal cytotoxicity and an only slightly reduced inhibition of cell growth as compared with anthralin. The homologous acid 7 was, however, completely inefficacious. Deriv. 8 and 9 are esters. In the case of $\mathbf{8}$ we found a decreased cytotoxicity with an equal inhibition of cell growth, and with 9 an equal cytotoxicity with a pronounced inhibition of cell growth, in comparison with anthralin. The ranking of drug potency by means of the HaCaT keratinocyte culture system was rather similar to that by means of the G-6-PDH assay ${ }^{25)}$ for deriv. 6,8 , and 9. In the case of 7 there was, however, a marked discrepancy between complete ineffectiveness in cell culture and an extremely low $\mathrm{IC}_{50}$-value of $0.9 \mu \mathrm{M}$ in the G-6PDH assay, which was more than eightfold lower than the reference value of anthralin.
Deriv. 8 and 9 also show activity similar to that of anthralin in the inhibition of leucotriene production; the acids 6 and 7, however, were more potent than anthralin. Their $\mathrm{IC}_{50}$-values for 5-lipoxygenase-inhibition were found to be between 5 and $10 \mu \mathrm{M}$ (anthralin: $\left.\mathrm{IC}_{50} \approx 40 \mu \mathrm{M}\right)^{42}$ ).

Concerning anthralin derivatives bearing acyl chains of different length at C-10 Mustakallio $^{43,44)}$ has already stated that at this position substituents less bulky than glucose do not hamper antiproliferative activity. Thus, in short contact therapy butantrone (syn. 10-butyryl-anthralin) was beneficial in the treatment of psoriasis. Its efficacy as well as irritancy and staining were, however, less than with anthralin. When conventionally applied for several $h$ per day over several weeks butantrone caused increased irritation as compared to anthralin. This was explained by a drug accumulation because of retarded degradation. The compound lacked any pro-drug character since anthralin was not produced as evidenced by HPLC analysis ${ }^{45}$. In HeLa cell cultures the antiproliferative activity of butantrone was confirmed ${ }^{46)}$, as was the case for the so-called 10-acetyl-anthralin, another C-10-derivative, which inhibited thymidine incorporation in human skin fibroblasts ${ }^{47)}$.

As a special example of C-10-liganding we studied bianthrone which - on an equimolar base - has an identical degree of cytotoxicity and growth inhibitory potency as anthralin. Conversely, in psoriasis Krebs and Schaltegger did 
Table 4: Activity of lactate dehydrogenase in the supernatants of keratinocyte cultures one day after treatment with anthralin, bianthrone, danthrone or anthralin derivatives 1 to 12 for $30 \mathrm{~min}$. The enzyme release from cytoplasm was taken as measure for cytotoxicity implying substantial plasma membrane damage. Significant differences at an overall level $\alpha<0.05$ are indicated by asterisks.

\begin{tabular}{|c|c|c|c|c|}
\hline \multirow{3}{*}{$\frac{\text { Incubation }}{\text { Test Compound }}$} & \multirow[t]{3}{*}{ Series } & \multicolumn{3}{|c|}{ Lactate Dehydrogenase release } \\
\hline & & \multirow[t]{2}{*}{$\begin{array}{l}\text { Percentage } \\
\text { ( mean } \pm \text { s.d. ) }\end{array}$} & \multicolumn{2}{|c|}{$\begin{array}{c}\text { Statistical Comparison ( } p \text { ) } \\
\text { of the Test compound } \\
\text { versus }\end{array}$} \\
\hline & & & Acetone & Anthralin \\
\hline Acetone & 1 & $100.0 \pm 36.7$ & - & $0.0000^{*}$ \\
\hline Anthralin & 1 & $641.1 \pm 195.3$ & $0.0000^{*}$ & - \\
\hline Bianthrone & 1 & $659.7 \pm 286.2$ & $0.0000^{*}$ & 1.0000 \\
\hline Danthrone & 1 & $150.1 \pm 65.8$ & 0.0625 & $0.0000^{*}$ \\
\hline Deriv. 1 & 1 & $129.5 \pm 44.2$ & 0.2973 & $0.0000^{*}$ \\
\hline Deriv. 3 & 1 & $75.9 \pm 32.4$ & 0.1135 & $0.0000^{*}$ \\
\hline Deriv. 5 & 1 & $126.5 \pm 42.6$ & 0.3865 & $0.0000^{*}$ \\
\hline Deriv. 7 & 1 & $161.7 \pm 51.3$ & 0.0188 & $0.0000^{*}$ \\
\hline Deriv. 8 & 1 & $392.8 \pm 74.3$ & $0.0000^{*}$ & $0.0008 *$ \\
\hline Deriv. 10 & 1 & $228.2 \pm 73.7$ & $0.0008^{*}$ & $0.0000^{*}$ \\
\hline Deriv. 12 & 1 & $434.7 \pm 156.4$ & $0.0000^{*}$ & 0.0315 \\
\hline Acetone & 2 & $100.0 \pm 34.7$ & - & $0.0000^{*}$ \\
\hline Anthralin & 2 & $685.0 \pm 97.8$ & $0.0000^{*}$ & - \\
\hline Deriv. 2 & 2 & $101.8 \pm 29.6$ & 0.6665 & $0.0000^{*}$ \\
\hline Deriv. 4 & 2 & $416.0 \pm 170.5$ & $0.0002^{*}$ & $0.0012^{*}$ \\
\hline Deriv. 6 & 2 & $640.1 \pm 147.8$ & $0.0000^{*}$ & 0.6048 \\
\hline Deriv. 9 & 2 & $803.6 \pm 207.5$ & $0.0000^{*}$ & 0.1359 \\
\hline Deriv. 11 & 2 & $712.1 \pm 177.3$ & $0.0000^{*}$ & 0.3401 \\
\hline
\end{tabular}

not observe a clearing efficacy of this dimeric compound ${ }^{36,37)}$, and it did not influence cell cycle kinetics in hairless mouse epidermis ${ }^{48}$. With regard to former in vitro studies the findings for bianthrone are also conflicting. It thus inhibited in comparison to anthralin a) the thymidine incorporation, glutamine respiration and $\mathrm{CO}_{2}$ production from glucose of SV-40 transformed human keratinocytes ${ }^{3)}$ as well as mitochondrial membrane functions ${ }^{5)}$ each to a lower degree and $b$ ) the thymidine incorporation and growth in human skin fibroblasts to a higher degree ${ }^{47,49)}$. Bianthrone did not alter the migration and superoxide anion production from human neutrophils in comparison to a solvent control $^{17}$. In vitro bianthrone produces the same radical species and decomposition products as anthralin ${ }^{50)}$.

\section{Significance of ligands replacing both hydrogens at C-10}

Deriv. 10, 11, and 12 bear lacton rings at $C-10$ consisting of four, five and six C-atoms, respectively. The keratinocyte growth inhibitory efficacy of all three derivatives exceeded that of anthralin, and deriv. 11 exerted the maximum effect ever recorded in our experiments. Therefore, it seems to be excluded that these anthralin derivatives act as pro-drugs by degradation to anthralin. In good agreement with these re- sults is the finding that deriv. 10 to 12 are potent lipoxygenase inhibitors, as well ${ }^{42}$. Their $\mathrm{IC}_{50}$-values were found to be about $2 \mu \mathrm{M}$ in our test system for derivatives 11 and 12; deriv. 10 was slightly less active $\left(\mathrm{IC}_{50} \approx 3 \mu \mathrm{M}\right)$. We found an identical cytotoxicity for deriv. 11 and 12 as compared to anthralin; a to some extent lower cytotoxic effect was only found in the case of deriv. 10.

With regard to substitution of both hydrogens at C-10, danthrone, clinically lacking any antipsoriatic quality 36,37 , may be regarded as a special case. Under our assay conditions this degradation product did not reveal any cytotoxicity. We found only a very minor inhibition of cell growth. In the micromolar range of concentration danthrone was, however, completely inactive concerning the proliferation as well as glucose- and glutamine-metabolism in keratinocyte cultures ${ }^{3)}$, the thymidine incorporation in fibroblasts ${ }^{47}$ and the motility and superoxide anion generation of neutrophils ${ }^{17}$. Concerning a multifunctional analysis of the interaction with the inner mitochondrial membrane danthrone is found to be almost inactive ${ }^{5}$. The slight growth inhibition effects observed in the $\mathrm{HaCaT}$ cells under danthrone might be explained by their especially high sensitivity due to a relatively short population doubling time of $21 \mathrm{~h}$ under the subconfluent growth conditions ${ }^{26)}$. 


\section{Conclusion}

There is good evidence by clinical and in vitro studies on different compounds (i.e. anthralin, danthrone, butantrone) that the antipsoriatic efficacy of a drug may be tested by its antiproliferative and cytotoxic effects in cell cultures ${ }^{1,3,29,46)}$. Employing such a keratinocyte assay the present results on anthralin derivatives mostly reveal a good correlation with the results gained by evaluating compounds' effects on G-6-PDH activity ${ }^{25)}$. There was only one compound [7] with a striking discrepancy between the cell culture and the enzyme assays. In the case of anthralin the sensitivity of the enzyme system $\left(\mathrm{IC}_{50}=8 \mu \mathrm{M}^{25}\right)$ ) is much lower as compared to the more complex HaCaT keratinocyte system $\left(\mathrm{IC}_{50}=0.2 \mu \mathrm{M}\right.$ for ${ }^{3} \mathrm{H}$-thymidine-incorporation ${ }^{27)}$ ). This obviously excludes G-6-PDH as a primary target for the drug's action. This conclusion is corroborated by studies concerning the intracellular distribution of ${ }^{14} \mathrm{C}$-anthralin, revealing that the cytosol remained essentially unlabeled ${ }^{3}$.

Substitution not only at C-1 (deriv. 1) and C-10 (deriv. 7) of the anthrone skeleton but also at C-2 (deriv. 3) may cause loss of efficacy, and, paradoxically, with an acetic acid ligand at C-2 (deriv. 2) we even observed a slight stimulation of cell growth. Among the anthralin derivatives tested we found seven compounds (deriv. 4, 6, 8, 9, 10,11, 12) exerting cell growth inhibitory and cytotoxic effects approximating or exceeding those of anthralin. For future investigations these substances would be of special interest as hydrophilic anthralin model compounds and antipsoriatic drugs.

The skillful technical assistance of Mrs. G. Franck and Mrs. V. Schlossberg is gratefully appreciated.

\section{References}

1 J.M. Clark and P.C. Hanawalt, J. Invest. Dermatol. 79, 18 (1982).

2 H. Pullmann, K. Enderer, and G.K. Steigleder, Br. J. Dermatol. 105 (Suppl. 20), 55 (1981).

3 U. Reichert, Y. Jacques, M. Grangeret, and R. Schmidt, J. Invest. Dermatol. 84, 130 (1985).

4 G.K. Steigleder, H. Schumann, and K.J. Lennartz, Arch. Derm. Forsch. 246, 231 (1973).

5 J. Fuchs, R. Milbradt, and G. Zimmer, Arch. Dermatol. Res. 282, 47 (1990).

6 J. Fuchs, W.H. Nitschmann, and L. Packer, J. Invest. Dermatol. 94, 71 (1990).

7 J. Fuchs, G. Zimmer, R.H. Wölbling, and R. Milbradt, Arch. Derm. Res. 279, 59 (1986).

8 P. Morliere, L. Dubertret, T. Sa E Melo, C. Salet, M. Fosse, and R. Santus, Br. J. Dermatol. 112, 509 (1985).

9 D. Cavey, J.C. Caron, and B. Shroot, Br. J. Dermatol. 105, (Suppl. 20), $15(1981)$.

10 H. Hammar, J. Invest. Dermatol. 54, 121 (1970).

11 A. Retzow, E. Plumier, and W. Wiegrebe, Pharm. Ztg. 126, 2150 (1981).

12 W.F.G. Tucker, S. MacNeil, R.A. Dawson, S. Tomlinson, and S.S. Bleehen, J. Invest. Dermatol. 87, 232 (1986).
13 J. Fuchs, Arch. Dermatol. 124, 849 (1988).

14 K.U. Schallreuter and M.R. Pittelkow, Arch. Dermatol. 123, 1494 (1987).

15 T. Lotti, L. Brunetti, and E. Panconesi, Arch. Dermatol. 122, 748 (1986).

16 C.J. Bedord, J.M. Young, and B.M. Wagner, J. Invest. Dermatol. 8l, 566 (1983).

17 J.M. Schröder, U. Kosfeld, and E. Christophers, J. Invest. Dermatol. 85,30 (1985).

18 R.E. Ashton, P. Andre, N.J. Lowe, and M. Whitefield, J. Am. Acad. Dermatol. 9, 173 (1983).

19 U. Reichert, Br. J. Dermatol. 115, (Suppl. 31), 108 (1986).

20 U. Reichert, R. Schmidt, and B. Shroot, J. Invest. Dermatol. 84, 302 (1985).

21 J. Fuchs and L. Packer, J. Invest. Dermatol. 92, 677 (1989).

22 P. Lambelet, J. Löliger, and B. Shroot, Skin. Pharmacol. I, 115 (1988).

23 K. Müller, W. Wiegrebe, and M. Younes, Arch. Pharm. (Weinheim) 320,59 (1987).

24 H. Tanzer, M. Seidel, and W. Wiegrebe, Arch. Pharm. (Weinheim) 321,447 (1988).

25 H. Tanzer, M. Seidel, and W. Wiegrebe, Arch. Pharm. (Weinheim) 322, 441 (1989).

26 P. Boukamp, R.T. Petrussevska, D. Breitkreuz, J. Hornung, A. Markham, and N.E. Fusenig, J. Cell. Biol. 106, 761 (1988).

27 B. Bonnekoh, B. Farkas, J. Geisel, and G. Mahrle, Arch. Dermatol. Res. 282, 325 (1990).

28 B. Bonnekoh, A. Wevers, F. Jugert, H. Merk, and G. Mahrle, Arch. Dermatol. Res. 281, 487 (1989).

29 E.B. Klem, J. Invest. Dermatol. 70, 27 (1978).

30 Anon, Z. klin. Chem. klin. Biochem. 8, 659 (1970).

31 M.A.E. Mol, J. Van Genderen, and O.L. Wolthuis, Fd. Chem. Toxic. 24, 519 (1986).

32 E. Duvall and A.H. Wyllie, Immunol. Today 7, 115 (1986).

33 M. Prunieras and C. Delescluse, Br. J. Dermatol. 27, 43 (1984).

34 H.B. Mann and D.R. Whitney, Ann. Math. Statist. 18, 50 (1947).

35 J.L. Fleiss, The design and analysis of clinical experiments, p. 105, Wiley, New York 1986.

36 A. Krebs and H. Schaltegger, Hautarzt 20, 204 (1969).

37 A. Krebs, H. Schaltegger, and A. Schaltegger, Br. J. Dermatol. 105 (Suppl. 20), 6 (1981).

38 F.F. Hellier and M. Whitefield, Br. J. Dermatol. 79, 491 (1967).

39 W. Wiegrebe, A. Gerber, J. Kappler, and C. Bayerl, Arzneim. Forsch. 29, 1083 (1979).

40 E. Plumier, B. Wappes, and W. Wiegrebe, Arch. Dermatol. Res. 276, 406 (1984).

41 W. Wiegrebe, A. Retzow, E. Plumier, N. Ersoy, A. Garbe, H.-D. Faro, and R. Kunert, Arzneim. Forsch. 34, 48 (1984).

42 H. Tanzer, C. Braun, M. Seidel, and W. Wiegrebe, Arch. Pharm. (Weinheim) 324, 841 (1991).

43 K.K. Mustakallio, Br. J. Dermatol. 105 (Suppl. 20), 23 (1981).

44 K.K. Mustakallio, In: C.E. Orfanos, R. Stadler, H. Gollnick (eds.) Proceedings of the XVII. world congress of dermatology 1987, p. 92, Springer, Berlin 1988.

45 J. Taskinen, J. Haarala, E. Wartiovaara, and J. Halmekoski, Arch. Pharm. (Weinheim) 321, 103 (1988).

46 A. Remitz, A.L. Kariniemi, E. Lehtonen, and S. Nordling, Br, J. Dermatol. 120, 525 (1989).

47 Y. Jacques and U. Reichert, Br. J. Dermatol. 105 (Suppl. 20), 45 (1981).

48 L.B. Fisher and H.I. Maibach, J. Invest. Dermatol. 64, 338 (1975).

49 P.J. Dykes, G.P. Roberts, and R. Marks, Br. J. Dermatol. 105 (Suppl. 20), $43(1981)$

50 A.G. Davies, J.A.-A. Hawari, and M. Whitefield, Tetrahedron Lett. 24 , 4465 (1983). 